\title{
A retrospective study of the prevalence of herpes simplex virus and herpes zoster virus infection
}

\author{
Maryam Radzuan*, Irna Sufiawati*, Dendi Sandiono* \\ *Departement of Oral Medicine Faculty of Dentistry Universitas Padjadjaran
}

\begin{abstract}
\end{abstract}
Introduction: Herpes simplex virus (HSV) and herpes zoster virus (HZV) are two members of the herpes virus family that can manifest in oral mucosa. Following primary infection, the viruses remain latent and may reactivate if the immune system becomes compromised. The purpose of this study was to know the prevalence and the site of manifestation of HSV and HZV infection in RSUP Hasan Sadikin Bandung from January 2007 until December 2011. Method: The method of this study was descriptive retrospective using secondary data and literature study. Data were taken from medical records of patients in RSUP Hasan Sadikin Bandung, from January 2007 until December 2011. The results were then presented in table and graphs. Result: The study's result showed the prevalence of HSV infection from 2007-2011 was $6 \%$ while the prevalence of HZV infection was $46 \%$. HSV and HZV infection occurred $41 \%$ at head and neck, $36 \%$ at trunk, $13 \%$ at extremities, $7 \%$ generalized, and $3 \%$ unspecified. The systemic diseases involved in these herpes viruses found in $20.3 \%$ patients. Conclusion: The conclusion of this study were the prevalence of HSV infection was low, while the prevalence of HZV infection was high. HSV infection frequently affected at head and neck, and HZV infection frequently affected the trunk. Systemic diseases involved in these herpes viruses were malignancies, neoplasm, internal organ disorders, skin diseases, blood disorder, and nerve disorder.

Keyword: Herpes simplex virus, herpes zoster virus, prevalence

\section{INTRODUCTION}

The human herpes virus family is known as Herpetoviridae, and its best-known member is herpes simplex virus and varicella-zoster virus, a DNA virus. ${ }^{1}$ Herpes virus infection spreads by direct intimate contact with lesions or secretions from an asymptomatic carrier. ${ }^{2}$ Latency is a characteristic of all herpes viruses, occurs when the virus is transported from mucosal or cutaneous nerve endings by neurons to ganglia where the herpes virus viral genome remains present in a nonreplicating state. Reactivation of the latent virus occurs when herpes virus switches to a replicative state which occur as a result of a number of factors including peripheral tissue injury from trauma or sunburn, fever, or immunosuppression. ${ }^{2,3}$

The prevalence of HSV-1 antibodies varies by country and type of population. In 1994 to 1995 in the general population in the United Kingdom, the HSV- 1 antibody prevalence was approximately $50 \%$ among individuals up to 30 years of age. In other 
adult populations in some European countries and in Africa, Asia, and Latin America, HSV-1 antibody prevalence was greater than $85 \% .4$.

A total of 1669 adult residents in United States with a confirmed diagnosis of HZV were identified between January $1^{\text {st }}, 1996$, and December $31^{\text {th }}, 2001$. Most $(92 \%)$ of these patients were immunocompetent and $60 \%$ were women. The incidence of $\mathrm{HZV}$ and the rate of $\mathrm{HZV}$-associated complications increased with age, with $68 \%$ of cases occurring in those aged 50 years and older.

The author carried out a retrospective study of the prevalence of HSV and HZV infection at RSUP Hasan Sadikin Bandung from January 2007 until December 2011 because it seems that these diseases prevalence are high worldwide and the epidemiologic data especially for developing country such as Indonesia is still lacking. In addition, there are no data on the prevalence of herpes simplex and herpes zoster infection in RSUP Hasan Sadikin Bandung until now. The purpose of

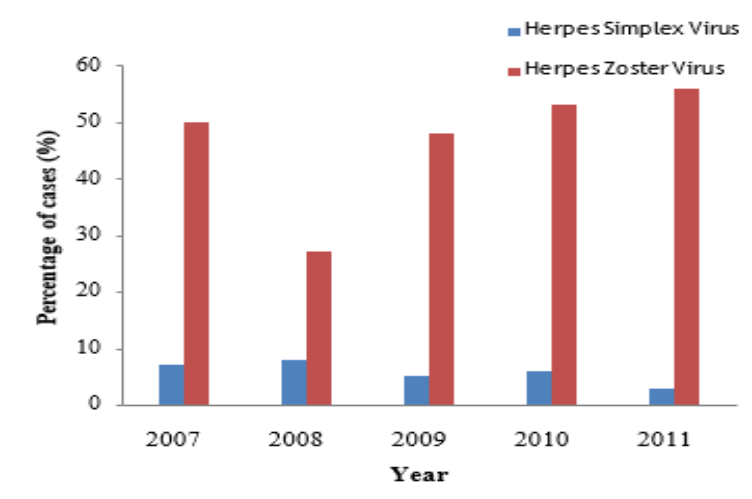

Figure 1. The Percentage of Cases with Herpes Simplex and Herpes Zoster Virus Infection in RSUP Hasan Sadikin Bandung According to the Year

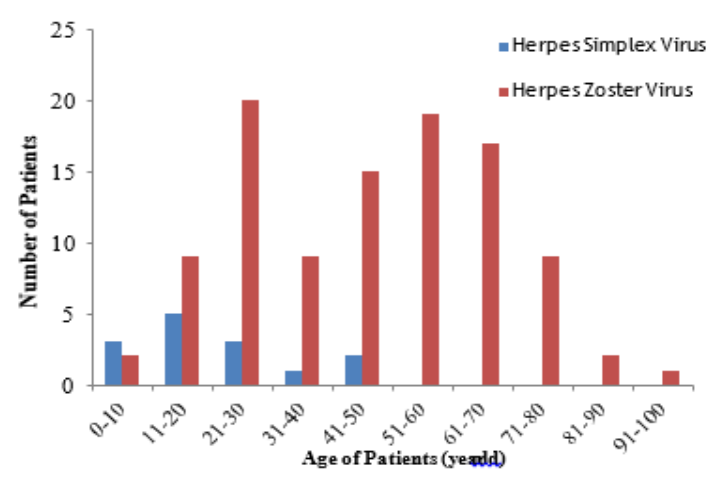

Figure 3 The Number of Patients with Herpes Simplex and Herpes Zoster Virus Infection in RSUP Hasan Sadikin Bandung According to Sex this study was to know the prevalence and the site of manifestation of HSV and HZV infection in RSUP Hasan Sadikin Bandung from January 2007 until December 2011.

\section{METHODS}

This is a descriptive retrospective type of research. The material used in this study is medical records in RSUP Hasan Sadikin Bandung from January 2007 until December 2011. Medical records with herpes simplex and herpes zoster virus infection at Medical Record Department in RSUP Hasan Sadikin, Bandung from January 2007 until December 2011 were collected and recorded in a table and graphs.

\section{RESULTS}

This study was done by collecting five-year medical records data from RSUP Hasan Sadikin

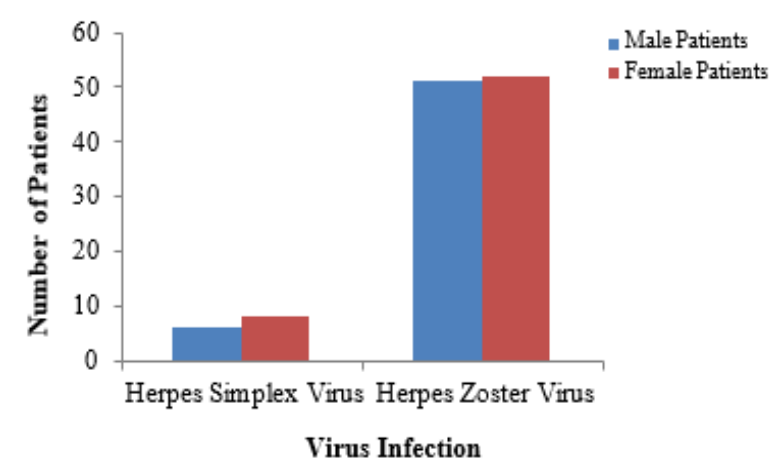

Figure 2. The Number of Patients with Herpes Simplex Virus and Herpes Zoster Virus Infection in RSUP Hasan Sadikin Bandung According to Age

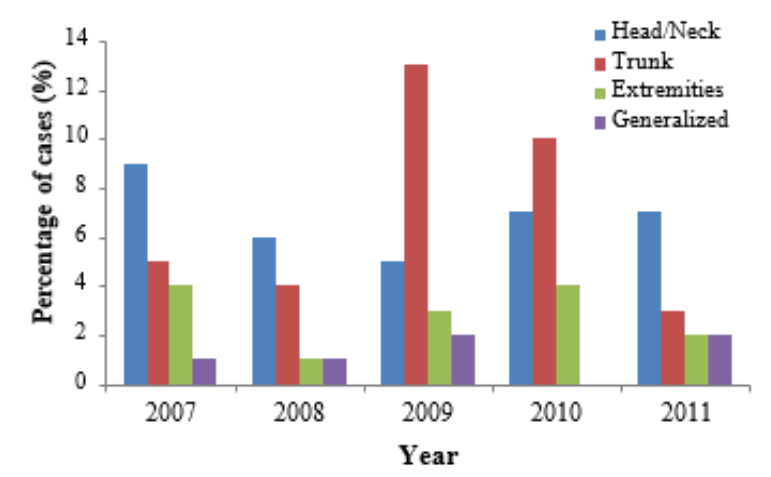

Figure 4 The Percentage of Cases with Herpes Zoster Virus Infection in RSUP Hasan Sadikin Bandung According to the Site of Manifestation 
Table 1. The Number of Patients with Herpes Simplex and Herpes Zoster in RSUP Hasan Sadikin Bandung According to the Systemic Disease

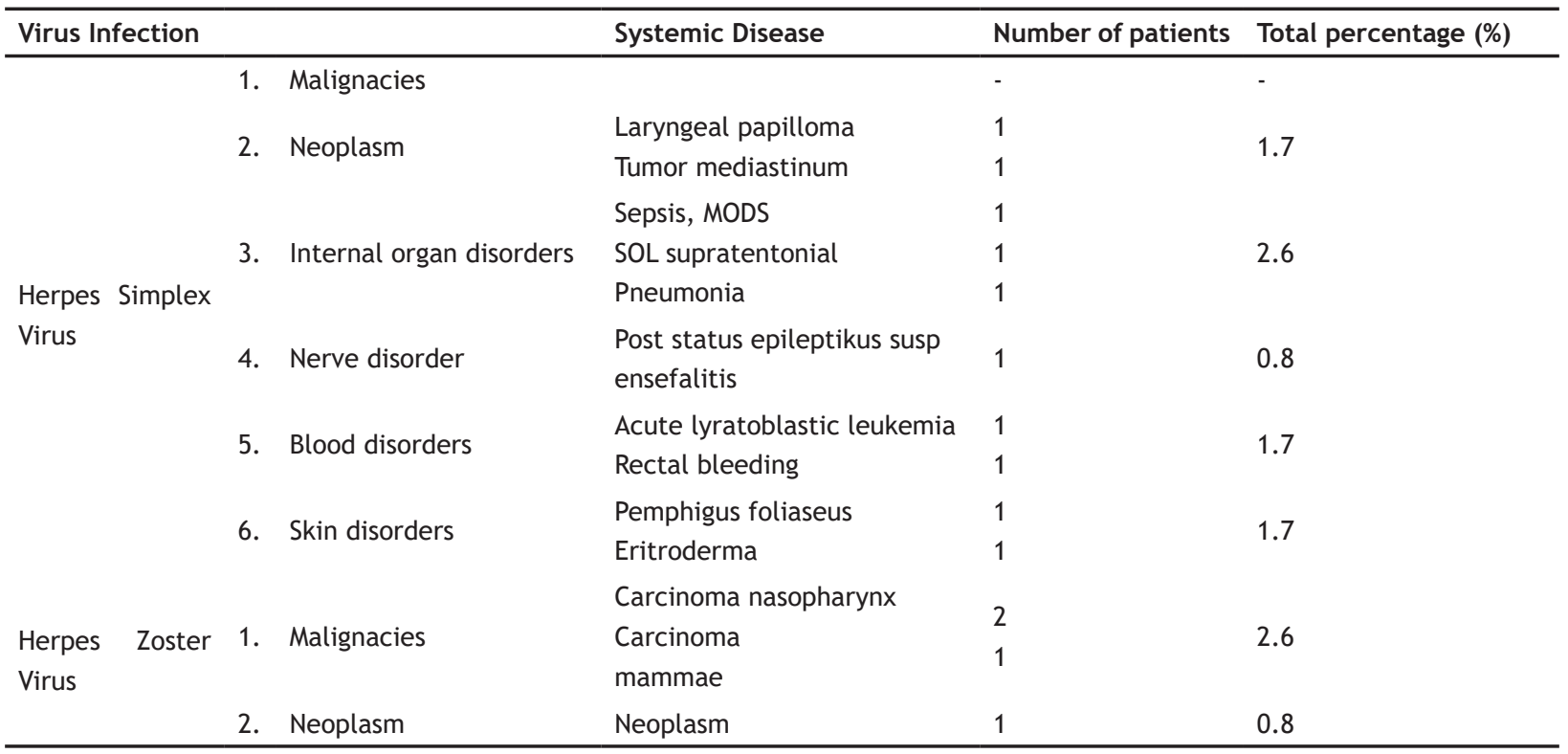

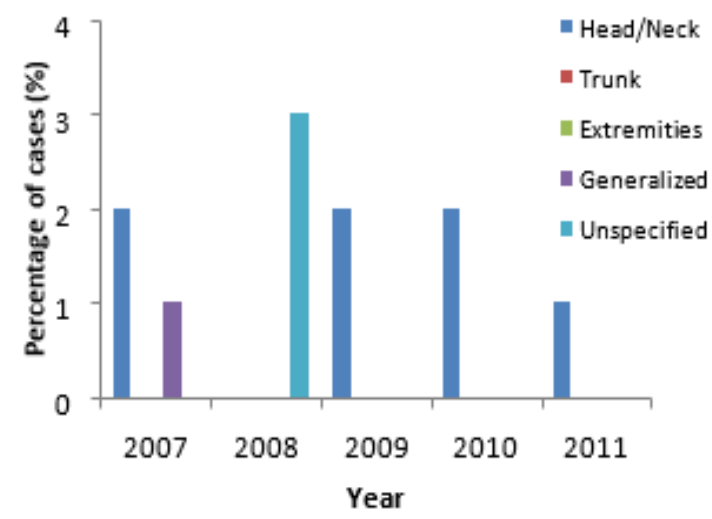

Figure 5 The Percentage of Cases with Herpes Simplex Virus Infection in RSUP Hasan Sadikin Bandung According to the Site of Manifestation

Bandung. In this study, there are 224 patients diagnosed with viral infections. From these 224 patients, the total number of patients with herpes simplex virus infection from January 2007 until December 2011 was 14 patients and the total number of patients with herpes zoster virus infection from January 2007 until December 2011 was 103 patients.

\section{DISCUSSION}

The results shown that the prevalence of herpes simplex virus infection at RSUP Hasan Sadikin, Bandung from January 2007 until
December 2011 was 14 cases (12\%). This result if compared to other research done by Cunnigham, et al. (2005) in Australia ${ }^{5}$, from 11,000 adults there were 8,360 adults (76\%) infected with HSV, means HSV prevalence in Bandung is lower than in Australia. Herpes simplex virus is a common viral infection that infected humans and it is one of known sexually transmitted infection, especially HSV-2. Although HSV-1 and HSV-2 manifest on different site of the body in majority of cases, changing of sexual habits are making the distinction less important. So it can be the answer of why the prevalence of HSV infection in Indonesia is lower than in Australia, because in Indonesia the citizens do not practice a free sex lifestyle and prostitution is highly forbidden.

The prevalence for herpes zoster virus infection at RSUP Hasan Sadikin, Bandung from January 2007 until December 2011 was 103 cases $(88 \%)$ and this result compared to research done by Rimland at Georgia, from 1506 cases there were 843 cases $(56.0 \%)$ represented herpes zoster infection. High prevalence of HZV seen in Bandung since Indonesia is a developing country compared to Georgia in United States of America which is a developed country, where the medications, environment, public health are better than developing country.

From 14 patients diagnosed with herpes simplex virus infection, the maximum number of 
cases was seen to be in the 11-20 year-old age group, which consists of 5 patients (4\%). It was reported by Cunningham, et al. that the highest in the 65-74 year-old age range (85\%). ${ }^{5}$ This difference may in part be due to the inclusion of older adults in the Australia survey, according to which seroprevalence value was ranged from 80.7 to $91.1 \%$ among adults 65 years of age and older. ${ }^{8}$ Different sampling strategies may also account for the differences.

The highest age range for patients with herpes zoster virus infection was 21-30 years old $(17 \%)$ and $51-60$ years old $(16 \%)$ which is contrast with other research done by Latheef at India where the maximum incidence was in the age group of 31-40 years (24\%) and with report done by Opstelten et al. where a total of $47 \%$ of all herpes zoster patients were at least 55 years old. ${ }^{6}$ Herpes zoster virus is known as the same virus causing chickenpox (varicella), and herpes zoster virus infection occurs as a reactivation of dormant virus of varicella zoster in patient, and this is triggered by certain risk factors such as stress, immunosuppression, occupational hazard, fatigue, age, trauma, and sunburn. So 21-30 years old age is a period one's finding a job or finished schooling, this may lead to stress or the job requires to stay outdoor more and this may lead to tiredness, sunburn and fatigue. As for 51-60 years old age group, this is when VZV-specific cellular immunity declining and also the antibody it self. ${ }^{6}$

This study showed that the result comprised of 6 male patients of herpes simplex virus infection (5\%), 8 female patients of herpes simplex virus infection (7\%), 51 male patients of herpes zoster virus infection (44\%), and 52 female patients of herpes zoster virus infection (44\%). Overall female patients were $60(51 \%)$ and male patients were $57(49 \%)$. The same result obtained from other reports. $4,7-10$ This is supported by the thought that women tend to be a sex-worker than men, women experienced certain risk factors such as menstruations and pregnancy which men do not experienced, women also tend to be more emotionally stress than men, and may be due to the difference in general population of females compared to males in Bandung city.

The data for herpes zoster virus infection shows the highest prevalent for site of manifestation is at the trunk with total 41 cases.
According to Rajendran ${ }^{11}$, initially, the adult patient exhibits fever, a general malaise, and pain and tenderness along the course of the involved sensory nerves, usually unilaterally. Often the trunk is affected. It is typically unilateral and dermatomic in distribution. ${ }^{11}$ The area supplied by the trigeminal nerve, particularly the ophthalmic division, and the trunk from T3 to L2 are most frequently affected; the thoracic region alone accounts for more than one-half of all reported cases, and lesions rarely occur distal to the elbows or knees. ${ }^{11,12}$

The tissues preferentially involved by the herpes simplex virus (HSV) are derived from the ectoderm and consist principally of the skin, mucous membranes, eyes, and the central nervous system. ${ }^{3}$ As in the result, the most prevalent site of manifestation for herpes simplex virus infection with total 9 cases is at the head or neck, specifically from the data it is herpes simplex labialis. Reactivation of virus from these primary infections involves the perioral facial area, mainly the lips, with the outer one-third of the lower lip being the most commonly affected, while other facial locations include the nose, chin, and cheek account for less than 10 percent of the cases. ${ }^{3,13}$

All manifestations of herpes simplex virus infection seen in the immunocompetent host can also be seen in immunocompromised patients but usually more severe, more extensive, and difficult to treat; and for many of them, recurrences are more frequent as well ${ }^{3}$. Recurrent infections occur periodically due to virus reactivation. ${ }^{10}$ Patients with defects of T-cell immunity are at particular risk for progressive mucocutaneous or visceral infections but, the degree of dissemination depends on the level of immunodeficiency of the host. Recurrent and persistent ulcerative HSV lesions are among the most common and defining opportunistic infections in patients with acquired immunodeficiency syndrome. ${ }^{3,10}$

The sequelae of herpes zoster include cutaneous, ocular, neurologic, and visceral complications. Most complications of herpes zoster are associated with the spread of VZV from the initially involved sensory ganglion, nerve, or skin, either via the bloodstream or by direct neural extension. When immunocompetent patients are carefully examined, it is not uncommon to have at least a few vesicles in areas distant from the 
involved and immediately adjacent dermatomes. ${ }^{12}$ The other well-defined risk factor for herpes zoster virus infection is altered cell-mediated immunity. Patients with neoplastic diseases (especially lymphoproliferative cancers), those receiving immunosuppressive drugs (including corticosteroids), and organ-transplant recipients are at increased risk for shingles. ${ }^{14}$ Disseminated disease, with mortality rate as high as $40 \%$, is a complication that is observed mainly in patients who are immunosuppressed. ${ }^{12,14}$

\section{CONCLUSION}

Prevalence of HSV infection waslow, while the prevalence of HZV infection was high. HSV infection frequently affected at head and neck, and HZV infection frequently affected the trunk. Systemic diseases involved in these herpes viruses were malignancies, neoplasm, internal organ disorders, skin diseases, blood disorder, and nerve disorder.

\section{REFERENCES}

1. Neville B, Damm DD, Allen CM, Bouquot J. Oral and Maxillofacial Pathology. $3^{\text {rd }}$ ed. Saunders. Noida. 2009. p. 240-48.

2. Greenberg MS, Glick M. Burket's Oral Medicine: Diagnosis and Treatment. $10^{\text {th }}$ ed. BC Decker Inc. Ontario. 2003. p. 51-57, 67-68, 75-76.

3. Sapp JP, Eversole LR, Wysocki GP. Contemporary Oral and Maxillofacial Pathology. $2^{\text {nd }}$ ed. Missouri Mosby. Ontario. 2004. p. 269-272.

4. Howard M, Sellors JW, Jang D, Robinson NJ, Fearon M, Kaczorowski J et al. Regional distribution of antibodies to herpes simplex virus type 1 (HSV-1) and HSV-2 in men and women in Ontario, Canada. J Clinical Microbiology 2003;41(1):84-9.

5. Cunningham, A.L.; Taylor, R.; Taylor, J.; Marks,
C.; Shaw, J.; and Mindel, A. 2005. Prevalence of infection with herpes simplex virus types 1 and 2 in Australia: a nationwide population based survey. J. of STI 82: 164-168.

6. Abdul Latheef EN1, Pavithran K. Herpes zoster: a clinical study in 205 patients. Indian J Dermatol. 2011 Sep-Oct;56(5):529-32.

7. Cowan F, Copas A, Johnson A, Ashley R, Corey, L, Mindel A. Herpes simplex virus type 1 infection: A sexually transmitted infection of adolescence? Sex Transm Infect. 2002 Oct; 78(5):346-8.

8. Cowan F, French R, Mayaud P, Gopal R, Robinson NJ, Oliveira SA et al. Seroepidemiological study of herpes simplex virus types 1 and 2 in Brazil, Estonia, India, Morocco, and Sri Lanka. Sex Transm Infect. 2003 Aug; 79(4): 286-290.

9. Tseng HF, Smith N, Harpaz R, Bialek SR, Sy LS, Jacobsen SJ. Herpes zoster vaccine in older adults and the risk of subsequent herpes zoster disease. JAMA 2011;305(2):212-4.

10. Vyse AJ, Gay NJ, Slomka MJ, Gopal R, Gibbs T, Morgan-Capner P, Brown DW. The burden of infection with HSV-1 and HSV-2 in England and Wales: implications for the changing epidemiology of genital herpes. Sex Transm Infect. 2000 Jun;76(3):183-7.

11. Rajendran R, Sivapathasundharam B. Shafer's Textbook of Oral Pathology. $6^{\text {th }}$ ed. Elsevier. Noida. 2009. p. 333-9, 344-47.

12. Wolff K, Goldsmith LA, Katz SI, Gilchrest BA, Paller AS, Leffell DJ. Fitzpatrick's Dermatology in General Medicine. $7^{\text {th }}$ ed. McGraw Hill. New York. 2008. p. 1873-98.

13. Douglas G, Couch RB. A prospective study of chronic herpes simplex virus infection and recurrent herpes labialis in humans. J Immunol. 1970 Feb;104(2):289-95.

14. Gnann JW, Whitley R. Herpes zoster. N Eng J Med. 2002;347(5):340-6. 